\title{
ANALISIS KADAR TIMBAL (Pb) DALAM RAMBUT DAN HIPERTENSI PADA PEKERJA PT. BUKIT ASAM UNIT DERMAGA KERTAPATI
}

\author{
Dini Arista Putri, Amrina Rosyada, Elvi Sunarsih \\ Fakultas Kesehatan Masyarakat Universitas Sriwijaya \\ Email: ${ }^{1}$ dini.aristaputri@unsri.ac.id

\section{ANALYSIS OF LEAD LEVEL IN HAIR AND HYPERTENSION OF WORKER IN BUKIT ASAM DOCK UNIT KERTAPATI}

\begin{abstract}
Background: Bukit Asam Dermaga Unit Kertapati conducts the process of dismantling coal from the train to barge. Then from a coal barge that is distributed for use as a power plant. Lead in coal into the body can cause hypertension because it directly affects the circulatory system, so this study aims to analyze the presence of lead content in coal that accumulates in the hair of workers of Bukit Asam Dock Unit Kertapati, which is associated with hypertension disease.

Methods: This research was conducted at Bukit Asam Dermaga Unit Kertapati used a cross sectional design with a sample of 38 people with multivariate analysis, where the completion of hair sample data was analyzed using Atomic Absorption Spectrophotometric (AAS) method and questionnaires distributed to respondents.

Results: The statistical analysis showed that every 1 year increase in the risk of increased 1,15 times for hypertension, BMI over weight category risk 5,87 times to suffer from hypertension compared to normal BMI. Coffee drinking habits at risk 1.4 times for hypertension, each 1-year increase in the risk of increased 1 time for hypertension.

Conclusion: The lead level in hair with hypertension, each increase of 1 unit of lead hypertension risk level decreased by 0.975 with confounding factor. The need for mask use of workers around the coal production area in order that can reduce lead exposure.
\end{abstract}

Keywords: Hypertension, lead, hair

\section{ABSTRAK}

Latar Belakang: PT. Bukit Asam Unit Dermaga Kertapati melakukan proses pembongkaran batubara dari kereta ke kapal tongkang. Kemudian dari kapal tongkang batubara yang didistribusikan untuk digunakan sebagai pembangkit Listrik. Timbal dalam Batubara yang masuk ke dalam tubuh dapat menyebabkan terjadinya hipertensi karena langsung mempengaruhi sistem peredaran darah, sehingga penelitian ini bertujuan untuk menganalisis adanya kandungan Timbal di batubara yang terakumulasi pada rambut pekerja PT. Bukit Asam Unit Dermaga Kertapati yang dihubungkan dengan penyakit hipertensi.

Metode: Penelitian ini dilakukan di PT. Bukit Asam Unit Dermaga Kertapati menggunakan desain crosssectional dengan jumlah sampel sebesar 38 orang dengan analisis multivariat, dimana pengumpulan data sampel rambut dianalisis menggunakan metode Atomic Absorption Spectrophotometry (AAS) dan kuesioner yang dibagikan kepada responden.

Hasil Penelitian: Hasil analisis statistik menunjukkan setiap kenaikan 1 tahun usia risiko meningkat 1,15 kali untuk menderita hipertensi, IMT kategori over weight berisiko 5,87 kali untuk menderita hipertensi dibandingkan IMT normal. Kebiasaan minum kopi berisiko 1,4 kali untuk menderita hipertensi, setiap kenaikan 1 tahun masa kerja risiko meningkat 1 kali untuk menderita hipertensi.

Kesimpulan: Kadar timbal di rambut dengan hipertensi, setiap kenaikan 1 satuan kadar timbal risiko hipertensi menurun sebesar 0,975 dengan faktor perancu yaitu usia. Sehingga perlunya penggunaan masker pada pekerja sekitar area produksi batubara untuk mengurangi paparan timbal.

Kata Kunci: Hipertensi, timbal, rambut

Alamat Koresponding: Dini Arista Putri, Fakultas Kesehatan Masyarakat Universitas Sriwijaya. Jl. Palembang Prabumulih KM. 32 , Indralaya Indah Kabupaten Ogan Ilir, Sumatera Selatan, email : dini.aristaputri@ unsri.ac.id 


\section{PENDAHULUAN}

Timbal merupakan logam beracun yang jumlahnya meningkat seiring dengan perkembangan industri di Indonesia. ${ }^{1}$ Timbal dapat mencemari udara, tanah, air, tumbuhan, hewan dan mempunyai dampak pada seluruh sistem di dalam tubuh. Batubara mengandung logam berat timbal karena proses pembentukannya dari dalam tanah. Berdasarkan Hasil penelitian Putri, Dalam limbah batubara yang telah diuji dengan menggunakan alat AAS (Atomic Absorption Spectrophotometry) ditemukan adanya kandungan timbal sebesar 2,96 ppm, 5,03 ppm dan 8,13 ppm dari 3 titik pengambilan yaitu Sungai Serut, Sungai Bengkulu dan Muara Pantai Panjang Bengkulu. ${ }^{2}$

Salah satu perusahaan Batubara di Palembang yaitu PT. Bukit Asam Unit Dermaga Kertapati melakukan proses pembongkaran batubara dari kereta ke kapal tongkang. Kemudian dari kapal tongkang batubara yang didistribusikan untuk digunakan sebagai pembangkit listrik ke batubara memungkinkan untuk mengandung logam berat timbal pada proses pembentukannya. Sehingga memungkinkan pekerja yang berada di sekitar lokasi terpapar langsung baik melalui inhalasi, absorbsi melalui kulit, makanan dan minuman akibat kurangnya kebersihan diri

Timbal yang masuk melalui makanan sekitar 5-10\% dari jumlah timbal yang masuk melalui makanan, mengendap pada jaringan tubuh seperti rambut $15 \%$, timbal yang terserap oleh darah berikatan dengan sel-sel darah merah (eritrosit) sekitar lebih dari 90\% logam, jumlah yang terhirup yang akan diserap oleh tubuh sebesar $30 \%$, sisanya terbuang melalui sisa metabolisme seperti urine dan feses. ${ }^{3}$

Timbal $(\mathrm{Pb})$ bersifat toksik, karsinogenik, bioakumulator dan biomagnifikasi. Timbal yang masuk kedalam tubuh dapat terakumulasi pada rambut, kuku dan hati. ${ }^{4}$ Timbal yang terpapar dalam rambut memiliki batas normal sebesar $\leq 12 \mu \mathrm{g} / \mathrm{g}$ sehingga apabila lebih dari batas tersebut dapat memiliki daya racun yang berbahaya sehingga menimbulkan efek bagi kesehatan. ${ }^{5}$ Salah satu kasus di daerah Chicago menunjukkan bahwa laporan berbasis kasus dalam literatur klinis selama tiga dekade terakhir telah menyajikan bukti sifat dan tingkat komplikasi jantung yang berkembang pada manusia sebagai respons terhadap keracunan timbal kronis dan akut, salah satunya hipertensi. Paparan timbal balik lingkungan dan pekerjaan yang meningkatkan kadar timbal di atas $100 \mu \mathrm{g} \%$ dan $60 \mu \mathrm{g} \%$. Timbal tersebut dapat menyebabkan efek kardiovaskular yang merugikan (yaitu, hipertensi) pada tingkat darah yang biasa ditemukan pada populasi yang terpapar. ${ }^{6}$

Rambut adalah bahan yang dapat mudah untuk dikumpulkan dan diawetkan sebagai sampel, sebagai upaya mendiagnosis penyakit dan tanda adanya polutan di lingkungan. ${ }^{7}$ Berdasarkan penelitian Novdian, seluruh rambut sopir bus yang diuji terdapat kandungan timbal dengan kadar timbal tertinggi pada masa kerja > 20 tahun, ${ }^{8}$ dan penelitian putra, menyatakan kadar timbal di dalam tubuh lebih banyak di dalam rambut dibandingkan kadar timbal di dalam kuku. ${ }^{9}$ Selain itu juga terdapat kandungan timbal di dalam urin. ${ }^{10}$ Kandungan timbal dalam rambut berisiko terhadap kejadian hipertensi pada pekerja yang terpapar secara langsung oleh limbah batubara, ${ }^{11}$ hal ini juga didukung oleh penelitian Fibriyanti menyatakan penambahan timbal $(\mathrm{Pb})$ dalam darah mempunyai hubungan dengan terjadinya hipertensi sehingga semakin tinggi kadar timbal $(\mathrm{Pb})$ dalam darah juga semakin berisiko untuk menderita hipertensi. ${ }^{12}$

Hipertensi bersifat Heterogenous Group of Disease karena dapat menyerang siapa saja dari berbagai kelompok sosial ekonomi dan sering disebut the silent killer. Hipertensi menimbulkan angka morbiditas (kesakitan) dan mortalitas (kematian) yang tinggi. ${ }^{13}$ Sehingga tujuan penelitian ini adalah 
menganalisis adanya kandungan timbal di batubara yang terakumulasi pada rambut pekerja PT. Bukit Asam Unit Dermaga Kertapati yang dihubungkan dengan penyakit hipertensi.

\section{METODE}

Penelitian ini menggunakan desain penelitian bersifat cross sectional. Subjek dalam penelitian ini adalah pekerja PT. Bukit Asam Unit Dermaga Kertapati. Teknik pengambilan sampel dengan pendekatan purposive dengan jumlah sampel sebanyak 38 responden dan pemeriksaan sampel rambut dengan metode analisis Atomic Absorbtion Spectrophotometry (AAS) serta kuesioner.
Analisis data menggunakan uji chi square dan uji regresi.

\section{HASIL PENELITIAN}

Pekerja yang bekerja di PT. Bukit Asam Unit Dermaga Kertapati memiliki kadar Timbal dalam rambut dengan nilai sebesar 43,39 $\mu \mathrm{g} / \mathrm{g}$ dan standar deviasi sebesar 24,51. Pekerja yang menderita tekanan darah tinggi (hipertensi) sebesar 42,1\%, dengan usia sekitar 23- 67 tahun, IMT dengan kategori normal $76,3 \%$, masa kerja diatas 4 tahun, pekerja dominan memiliki kebiasaan merokok 10-20 batang, kebiasaan minum kopi $>1$ kali perhari.

Tabel 1.

Full model: Hubungan dan Besar Risiko Antara Kadar Timbal dalam Rambut, Usia, IMT, Kebiasaan Minum Kopi, Kebanyakan Merokok dan Masa Kerja dengan Hipertensi

\begin{tabular}{lcccc}
\hline \multicolumn{1}{c}{ Variabel } & \multirow{2}{*}{ Sig } & \multirow{2}{*}{ OR } & \multicolumn{2}{c}{ 95\% CI } \\
\cline { 5 - 5 } \cline { 4 - 5 } Kadar timbal dalam rambut & 0.253 & 0.977 & 0.938 & 1.017 \\
Usia & 0.009 & 1.152 & 1.037 & 1.281 \\
IMT & 0.106 & 5.868 & 0.687 & 50.157 \\
Kebiasaan minum kopi & 0.419 & 1.438 & 0.596 & 3.469 \\
Kebiasaan merokok & 0.223 & 0.204 & 0.016 & 2.636 \\
Masa Kerja & 0.992 & 1.000 & 0.994 & 1.006 \\
\hline
\end{tabular}

Berdasarkan tabel 1, setiap kenaikan 1 tahun usia risiko meningkat 1,15 kali untuk menderita hipertensi, IMT kategori over weight berisiko 5,87 kali untuk menderita hipertensi dibandingkan normal, kebiasaan minum kopi berisiko 1,4 kali untuk menderita hipertensi, setiap kenaikan 1 tahun masa kerja risiko meningkat 1 kali untuk menderita hipertensi. Kemudian untuk variabel kadar timbal dalam rambut memiliki nilai CI $(0,938$ $0,1017)$ dan kebiasaan merokok memiliki nilai CI $(0,016-2,636)$.

Tabel 2.

Final Model: Hubungan dan Berisiko Antara Kadar Timbal Rambut dan Usia dengan Hipertensi

\begin{tabular}{lcccc}
\hline \multicolumn{1}{c}{ Variabel } & \multirow{2}{*}{ Sig } & \multirow{2}{*}{ OR } & \multicolumn{2}{c}{ 95\% CI } \\
\cline { 5 - 6 } & & & Lower & Upper \\
\hline Kadar timbal dalam rambut & 0.155 & 0.975 & 0.941 & 1.010 \\
Usia & 0.016 & 1.115 & 1.020 & 1.218 \\
\hline
\end{tabular}

Berdasarkan tabel 2, setiap kenaikan 1 satuan kadar timbal, risiko hipertensi menurun sebesar 0,975 . Setelah dikontrol variabel usia dan setiap kenaikan 1 tahun usia maka risiko untuk hipertensi meningkat sebesar 1,115.

\section{PEMBAHASAN}

Kegiatan industri pertambangan batubara dapat menimbulkan polusi udara dan gangguan kesehatan pada pekerja yang 
langsung terpapar batubara, Hal ini dikarenakan debu, tumpahan bahan kimia, asap-asap yang beracun, logam-logam berat dapat meracuni penambang dan menyebabkan gangguan kesehatan sepanjang hidup. ${ }^{14} \mathrm{Pada}$ pengujian awal batubara di wilayah kerja legal yakni PT. Unit Dermaga Kertapati ditemukan adanya kandungan timbal dalam batubara sebesar $<0.05 \mathrm{ppm}$ dan 0,84 ppm. Timbal yang terkandung di dalam batubara dapat masuk ke dalam tubuh pekerja yang berada di sekitar lokasi terpapar langsung baik melalui inhalasi, absorpsi melalui kulit, makanan dan minuman akibat kurangnya kebersihan diri. Timbal yang masuk melalui makanan sekitar 5-10\% dari jumlah timbal yang masuk melalui makanan, mengendap pada jaringan tubuh seperti rambut $15 \%$, timbal yang terserap oleh darah berikatan dengan sel-sel darah merah (eritrosit) sekitar lebih dari 90\% logam, jumlah yang terhirup yang akan diserap oleh tubuh sebesar $30 \%$, sisanya terbuang melalui sisa metabolisme seperti urine dan feses.

Timbal dapat menimbulkan penyakit antara lain anemia, ${ }^{15}$ kelelahan kerja, ${ }^{16}$ gangguan ginjal dan hematologis, ${ }^{17}$ gangguan fungsi hati, ${ }^{18}$ gangguan hipotiroidisme, ${ }^{19}$ hipertensi. ${ }^{12}$ Timbal di dalam darah secara langsung mempengaruhi sistem peredaran darah sehingga dapat meningkatkan produksi Reactive Oxygen Species (ROS). ROS dapat meningkatkan tekanan darah dan mempengaruhi perubahan atheroscleorotic dalam darah arteri dan gangguan jantung. ${ }^{20}$

Berdasarkan hasil analisis statistik, setiap kenaikan 1 satuan kadar timbal dalam rambut menurunkan risiko sebesar 0,975 untuk terjadi hipertensi. Hal ini sejalan dengan penelitian Putri yang menyatakan bahwa pekerja memiliki kadar timbal dalam rambut > $12 \mu \mathrm{g} / \mathrm{g}$ menderita penyakit hipertensi dibandingkan dengan kadar timbal $<12 \mu \mathrm{g} / \mathrm{g}$ dan tidak hipertensi. ${ }^{2}$ Logam berat dalam tubuh manusia biasanya terakumulasi pada beberapa organ tubuh seperti ginjal, hati, kuku, jaringan adiposa, dan rambut.
Analisis kandungan logam berat pada darah ataupun urin tidak akurat. Logam berat yang berada pada darah atau urine tidak bertahan lama dan dapat segera dikeluarkan melalui siklus metabolisme tubuh sedangkan analisis logam berat melalui rambut lebih akurat. Hal ini disebabkan logam berat lebih bertahan lama di rambut. Jumlah logam dalam rambut berkorelasi dengan jumlah logam yang di absorpsi oleh tubuh. Oleh karena itu, rambut dapat dipakai sebagai biopsi material. ${ }^{21}$ Rambut dapat digunakan sebagai indikator pencemaran pada orang-orang di daerah industri berdasarkan tingkat mobilitas atau lamanya interaksi dengan pencemar logam timbal $(\mathrm{Pb})$. Selanjutnya rambut secara unik juga dapat digunakan untuk membedakan pencemaran timbal $(\mathrm{Pb})$ yang bersifat internal dan eksternal. ${ }^{22}$

Faktor Indeks massa tubuh (IMT) berisiko 5,87 kali untuk menderita hipertensi. Berdasarkan penelitian Estiningsih menyatakan bahwa indeks massa tubuh secara signifikan berhubungan dengan kadar lemak tubuh total sehingga dapat dengan mudah mewakili kadar lemak tubuh, ${ }^{23}$ dan juga IMT berkorelasi langsung dengan tekanan darah, terutama tekanan darah sistolik. Pengidap kegemukan yang ditandai dengan nilai Indeks Massa Tubuh (IMT) $>25 \mathrm{~kg} / \mathrm{m}^{2}$ lebih berisiko menderita hipertensi dibandingkan dengan IMT $<25 \mathrm{~kg} / \mathrm{m}^{2}$. $^{24}$

Faktor kebiasaan merokok pada hasil penelitian ini bersifat protektif terhadap kejadian hipertensi. Hal ini bertentangan dengan penelitian Rahajeng menyatakan bahwa kebiasaan merokok dapat memicu timbulnya penyakit hipertensi sebesar 1,1 kali dibandingkan yang tidak merokok. Rokok dapat mengakibatkan vasokonstriksi pembuluh darah perifer dan pembuluh di ginjal yang menyebabkan meningkatnya tekanan darah. Merokok secara aktif maupun pasif dasarnya mengisap $\mathrm{CO}$ (karbon monoksida) yang mempunyai kemampuan mengikat hemoglobin $(\mathrm{Hb})$ yang terdapat dalam sel darah merah (eritrosit) lebih kuat 
dibanding oksigen. Sel tubuh yang menderita kekurangan oksigen akan berusaha meningkatkan yaitu melalui kompensasi pembuluh darah dengan jalan menciut atau spasme dan mengakibatkan meningkatnya tekanan darah. ${ }^{25}$

Kebiasaan minum kopi berisiko 1,4 kali untuk menderita hipertensi dibandingkan respon yang tidak memiliki kebiasaan minum kopi. Peningkatan tekanan darah terjadi melalui mekanisme biologi antara lain kafein mengikat reseptor adenosin, mengaktifasi sistem saraf simpatik dengan meningkatkan konsentrasi cathecolamines dalam plasma, dan menstimulasi kelenjar adrenalin serta meningkatkan produksi kortisol yang berdampak vasokontriksi dan meningkatkan total resistensi perifer yang menyebabkan tekanan darah menjadi meningkat. ${ }^{26}$

Faktor usia beresiko 1,15 kali untuk menderita hipertensi, Hal ini mendukung penelitian Apriyandi menyatakan bahwa faktor usia yang lebih dari 45 tahun maka angka hipertensi akan semakin tinggi karena degeneratif. ${ }^{27}$ Dilihat dari subjek yang lakilaki, semakin banyak laki-laki yang ada maka faktor risiko hipertensi akan meningkat. Penelitian Price menyatakan bahwa penyebab hipertensi dapat disebabkan pula oleh penurunan elastisitas pembuluh darah sehingga pembuluh darah menjadi kaku. Pembuluh darah tidak dapat menjalankan fungsinya dengan baik untuk mengembang pada saat jantung memompa darah melalui pembuluh darah, sehingga jantung harus meningkatkan denyutnya pada pembuluh darah yang menyempit agar aliran darah dapat didistribusikan ke seluruh tubuh. ${ }^{28} \mathrm{Hal}$ ini menyebabkan naiknya tekanan darah, dan berdasarkan hasil final model diketahui bahwa variabel usia sebagai faktor perancu dalam

\section{DAFTAR PUSTAKA}

1. Ahmed F, Pervez, Khatoon, Mustaq, Batool. Association of Lead with Heamoglubin damage in males (car painters) of Lahore. J Dent Med Sci. penelitian ini dengan menunjukkan setiap kenaikan 1 tahun usia maka risiko untuk hipertensi meningkat sebesar 1,115. Paparan timbal dari batubara secara langsung selama 8 jam/hari menyebabkan semakin besarnya peluang setiap responden berisiko hipertensi sehingga perlunya peraturan lebih ketat mengenai penggunaan APD khususnya masker pada pekerja sekitar area produksi batubara.

\section{UCAPAN TERIMA KASIH}

Penulis mengucapkan terima kasih kepada Lembaga Penelitian dan Pengabdian Kepada Masyarakat (LPPM) yang telah memberikan dukungan finansial terhadap penelitian ini.

\section{KESIMPULAN DAN SARAN}

Kandungan timbal dalam rambut pekerja PT. Bukit Asam unit Dermaga Kertapati rata-rata sekitar $43.39 \mu \mathrm{g} / \mathrm{g}$. Pengaruh kadar timbal di rambut dengan hipertensi, setiap kenaikan 1 satuan kadar timbal risikonya meningkat sebesar 0,975 untuk terjadi hipertensi dan variabel usia sebagai faktor perancu. Hipertensi dapat disebabkan oleh timbal karena sebelum sampai ke rambut, timbal yang ada di dalam darah secara langsung mempengaruhi sistem peredaran darah.

Saran dari penelitian ini adalah Pekerja diharapkan untuk menggunakan alat pelindung diri saat memasuki area kerja untuk meminimalisir paparan timbal akibat batubara dan pekerja harus mengontrol gaya hidup yang tidak baik, hal ini terlihat dari IMT, kebiasaan merokok dan kebiasaan minum kopi dari pekerja PT. Bukit Asam Unit Dermaga Kertapati.

2014;13:33-8.

2. Putri DA, Sutomo A heru, Prawiroharjono W. Hubungan Akumulasi Timbal pada Rambut Masyarakat Pengumpul Limbah Batubara di Air 
Sungai Bengkulu dengan Penyakit Hipertensi. Jurna 1 Media Kesehat. Universitas Gadjah Mada; 2015;8(2).

3. Palar. Pencemaran Dan Toksikologi Logam Berat. Jakarta: Rineka Cipta; 2012.

4. Marianti, Prasetya. Rambut Sebagai Bioindikator Pencemaran Timbal pada Penduduk di Kecamatan Semarang Utara. Biosantifika. 2013;

5. Palar. Pencemaran dan Toksikologi Logam Berat. Jakarta: Rineka Cipta; 1994.

6. Kopp BSJ, Barron JT, Tow JP. Cardiovascular Actions of Lead and Relationship to Hypertension : A Review. 1988;78:91-9.

7. Kubova, Stersko, Meved, Polakovicova. analysis of human hair- reliable tool for monitoring of contamination of environmental exposure. Acta Environmetalica Univ comenianae. 1994;2.

8. Novdian S. Gambaran Kadar Timbal $(\mathrm{Pb})$ dalam Rambut Sopir Bus yang Melewati Jalur Transportasi Ujung Gading-Padang pada Tahun 2016. Universitas Andalas; 2016.

9. Putra W., Amin B, Anita S. Kadar Timbal $(\mathrm{Pb})$ pada Rambut dan Kuku Polisi Lalu Lintas di Kota Pekanbaru dan Kota Bengkalis. Din Lingkung Indones. 2015;121-8.

10. Irwansyah $\mathrm{T}$, Broto $\mathrm{M}$. Hubungan Kepadatan, Jenis Kendaraan terhadap Kadar Timbal Udara dan Urin Masyarakat Sekitar Jalan Raya Kota Yogyakarta. J Mns dan Lingkung. 2003;10:10-8.

11. Putri D., Sutomo A., Widharto. Hubungan Akumulasi Timbal pada Rambut Masyarakat Pengumpul Limbah Batubara di Air Sungai Bengkulu dengan Penyakit hipertensi. Universitas Gadjah Mada; 2015.

12. Fibriyanti L., Azizah R. Karakteristik, Kadar Timbal $(\mathrm{Pb})$ dalam Darah, dan Hipertensi Pekerja Home Industry Aki Bekas di Desa Talun Kecamatan Sukodadi Kabupaten Lamongan. Jurna; Kesehat Lingkung. 2015;8:92-102.

13. Susilo T, Wulandari A. Cara Jitu Mengatasi Hipertensi. Yogyakarta: Penerbit Andi; 2011.
14. Juniah R, Dalimi R, Suparmoko M, Setyo S. Dampak Pertambangan Batubara Terhadap Kesehatan Masyarakat Sekitar Pertambangan Batubara (Kajian Jasa Lingkungan Sebagai Penyerap Karbon). J Ekol Kesehat. 2013;12.

15. Lubis $B$, Rosdiana N, Nafianti $S$, Rasyianti O, Panjaitan F. Hubungan Keracunan Timbal dengan Anemia Defi siensi Besi pada Anak. Medan; 2013.

16. Parinding G., Djajakusli R, Russeng S. Hubungan Antara Kadar Timbal dalam Darah dengan Kelelahan Kerja Pada Tukang Ojek di Pangkalan Ojek BTP Kecamatan Tamalanrea Kota Makassar Tahun 2013. Universitas Hasanuddin; 2013.

17. Muliyadi M. Paparan Timbal Udara terhadap Timbal Darah, Hemoglobin, Cystatin C Serum Pekerja Pengecatan Mobil. J Kesehat Masy. 2015;11.

18. Fidiyatun, Setiani, Suhartono. Hubungan Kadar $\mathrm{Pb}$ dalam Darah dengan Kejadian Gangguan Fungsi Hati pada Pekerja Peleburan Timbah Hitam di Kabupaten Tegal. Kesehat Lingkung. 2013;12(2):149-53.

19. Hidayati, Suhartono, Nurjazuli. Hubungan kadar Pb dalam Darah dengan Kejadian Hipotiroidisme pada wanita Usia Subur di Perkampungan Usaha Kecil dan Mengengah Desa Pesarean Kabupaten Tegal. Kesehat Lingkung Indones. 2013;

20. Farmand F, Ehdaie A, C.H.K R, R.K S. Lead-Induced Dysregulation of Superoxide Dismutases, Catalase, Glutathione Peroxidase and Guanylate cyclase. Environ Res. 2005;98(1):33-9.

21. Wilson L. Hair Mineral Analysis - An Introduction. LD Wilson Consultants,Inc. 2016;

22. Slamet J. Kesehatan Lingkungan. Yogyakarta: Gadjah Mada University Press; 2002.

23. Estianingsih $\mathrm{H}$. Hubungan Indeks Massa Tubuh dan Faktor Lain dengan Kejadian Hipertensi pada Kelompok Usia 18-44 tahun diKelurahan Sukamaju Depok Tahun 2012. Universitas Indonesia; 2012.

24. Kristina K, Pangaribuan L, Bisara D. Hubungan Index Massa Tubuh dengan 
Hipertensi pada Wanita Usia Subur (Analisis Data Riskesdas 2013). J Kesehat Reproduksi. 2015;6.

25. Rahajeng E, Tuminah S. Prevalensi Hipertensi dan Determinannya di Indonesia. Majalah Kedokteran Indonesia. 2009;

26. Artiyaningrum B, Azam M. FaktorFaktor yang Berhubungan dengan Kejadian Hipertensi Tidak Terkendali pada Penderita yang Melakukan Pemeriksaan Rutin. Sci J Unnes. 2016;1.

27. Apriyandi F. Hubungan antara peningkatan usia dengan kejadian hipertensi pada pasien yang berobat jalan dirumah sakit Bhineka Bakti Husada pada tanggal 19 sampai 31 Juli 2010. Universitas Isalam Negeri; 2010.

28. Price W. Patofisiologi Volume 2. Jakarta: Penerbiy Buku Kedokteran EGC; 2006. 